\section{Gendered discourse in Swedish national alcohol policy action plans 1965-2007: Invisible men and problematic women}

\section{Introduction}

Historically, different moral standards have been applied to women's and men's consumption of alcohol. In Sweden, during the rationbook period in 1919-55, all use of alcohol by women was seen as a moral deviation, and women were issued with ration books with utmost restrictiveness (Bruun 1985). Not only were women more contested in moral terms, but they were also attributed the role of the guardian of morality as the state's extended arm in the individual control of men's alcohol consumption. A new era commences with the abolition of the ration book, increasingly shifting the object of control away from the individual and his/her possibly deviant behaviour to risk-creating factors in the environment. At the same time, in a contrasting process, the methods of control move from external authorities such as the police and government officials to the individual in terms of individual responsibility and self-regulation (Tigerstedt 1999). Although societies with the most clearly divided gender roles appear to have the biggest differences between men's and women's drinking patterns (Wilsnack \& Wilsnack 1997), moral norms dictate differ-

\section{ABSTRACT}

M. Abrahamson \& K. Heimdahl:

Gendered discourse in Swedish national alcohol policy action plans 1965-2007: Invisible men and problematic women

In a critical discourse analysis of Swedish alcohol policy action plans, we have compared five different documents between 1965-2007 to examine problems with and reasons for women's and men's drinking, and recommendations for policy actions. The results display a hierarchical logic between the genders. During the early years, men's drinking is implicitly constituted as the norm. A basic tenet is that female and male drinking are the same. Women may drink less, but their drinking is not of a different character. It is highly exceptional to make a separation between men's and women's drinking. In later documents, however, the separation of these spheres results in female drinking being depicted as more problematic because of women's more vulnerable condition and individual psychological reasons. In order to highlight female drinking problems, male drinking is being erased from the picture and constructed in a positive contrast. As a consequence, men's drinking is normalised. Finally, in the most recent documents, attention has exceedingly shifted to women as containers of the foetus and to young women's and girls' sexual behaviour and psychiatric problems.

\section{KEYWORDS}

Swedish alcohol policy action plans, discourse analysis, women and men 
ent and narrower limits for women than for men in accepted behaviour even in Sweden and other more gender egalitarian societies (Abrahamson 2003; Measham 2002).

By analysing alcohol policy action plans behind the policy after the abolition of the ration book, we shall draw attention to the various images of women and men and to expectations of self-regulation. Before going into a detailed analysis of the documents, we will briefly discuss changes in alcohol consumption in 1919-55, gender differences in drinking patterns and perceived consequences of drinking.

\section{Women's and men's alcohol consumption and perceived problems}

The decision to abolish the ration-book system was taken following a wealth of studies led by the Temperance Committee appointed in 1944. One of these studies, completed in 1950, did the sampling in such a way as excluded women from the study altogether, although the goal was to map the alcohol habits and the extent of related problems in the whole population (Knobblock 1995, 117ff). Suffused with the view of women as abstainers, the committee failed to see that the proposed reform would allow women, too, free access to buy alcohol. The previous normative idea of "sober women" has thus probably rendered women's drinking both invisible and underestimated (Eriksen 1999; Fillmore 1984). With the waiver of the ration-book system in 1955, women were also recognised as alcohol consumers as such, albeit considerably more cautious consumers than men.

The few previous studies of the adult population's drinking habits show a change in the gender balance of alcohol consumption during the 1970s. Since then, the ratio has remained surprisingly stable. In a compilation of such studies, Leifman (2003) portrays the distribution of women's and men's share of total alcohol consumption for different years. In 1968 women accounted for $20 \%$ of the total consumption, while men stood for $80 \%$. In 1978, the women's share amounted to $27 \%$, in 1990 to $25 \%$, in 1996 to $30 \%$, in 1998 to $31 \%$, in 2000 to $29 \%$, and in 2002 to $30 \%$. The continuous monitoring of Swedish alcohol habits undertaken at the Centre for Social Research on Alcohol and Drugs (SoRAD) since 2000 shows that the gender ratio of the total alcohol consumption has remained relatively unchanged since the mid-1990s: women drink 30 percent of the alcohol consumed in Sweden, while men account for 70 percent of the total (see, e.g. Boman et al. 2006). In relation to men's alcohol consumption, the women's share changed most during the 1970s. The change has since been only minor.

Alcohol consumption has increased steadily throughout the industrialised world during the post-war period (Mäkelä et al. 1981). Swedish alcohol consumption has increased particularly dramatically since membership in the European Union in 1995 and the period thereafter. In the early 1990s, before entry in the EU, annual consumption was estimated at 7.7 litres of pure alcohol per person (Leifman 2003), rising to 10.5 litres in 2004 (Boman et al. 2006) and then gradually decreasing slightly to the current 9.8 litres (SoRAD 2008). From 1996 to 2002, when consumption grew the most, surveys of self-estimat- 
ed consumption show an increase from 1.9 litres to 2.5 litres for women and from 4.3 litres to 5.6 litres for men. This amounts to a relative increase of approximately 30 percent for both genders (Leifman 2003).

In addition to women and men drinking varying amounts of alcohol, there is also variation in the ways of drinking and in drink-related harms and problems. A Swedish survey showed that those who drink the most tend to be men, young people of both sexes, people with high incomes, and with an education up to and above high-school level. They also binge drink more frequently than others (Hradilova Selin 2004a). The perceived negative consequences of binge drinking are impaired self-control, problems with law and order, health issues and trouble with social relationships. For women, frequent drinking does not imply an increase in such problems, whereas it does for men (Ramstedt 2004). Most types of problems are about twice as common with men, and trouble with law and order even four times as customary (Hradilova Selin 2004b).

The above summary of the continuous gap between men's and women's consumption suggests a political challenge. Alcohol policy measures have increasingly come to consist of local prevention and risk information. The prevention efforts and messages about alcohol risks and help for people with alcohol problems should be perceived as adequate by men - young men in particular - and high earners, that is, by those who should be the primary subjects of these efforts. The topic of this article has an indirect bearing on the issue, discussing how alcohol policy action plans address women's and men's alcohol consumption, what the consumption is seen to entail and how it is explained and problematised.

\section{Discourse Analysis: Theory and method}

Our analysis is guided by Fairclough's critical discourse analysis, which has an important point of departure in a dialectic relation between the discourse and the surrounding social structures. Discourse is shaped and imposed by social structures at different levels while at the same time constituting the social environment. Discourse contributes to a construction of the social structures, which are directly or indirectly affected by it (Fairclough 1992). It also helps to create social identities and social relationships between people and to create systems of knowledge and meaning. In Fairclough's model of discourse analysis, discourse is seen as a three-dimensional concept, acting on three different levels: as text, as discursive practice and as social practice.

We have structured our material with this three-dimensional concept in mind. The first dimension, discourse as text, is analysed by examining the modality, or the degree of certainty, belief and commitment in a statement (Fairclough 1992). Discourse as text also includes transitivity: how are persons and events described, as agents with intentions or as passive recipients of others' actions?

The second dimension, the discursive practice, is relevant when examining what kind of interdiscursivity is involved. For example, how does the terms of reference preceding a report show in the text and are there perhaps several, at times contradictory, alcohol policy discourses running in parallel? High interdiscursivity can be 
seen as a sign of change and struggle over the discursive order, whereas low interdiscursivity can be interpreted as a sign of stability. Furthermore, we will place the documents in their social, cultural and political contexts, highlighting current dominant explanatory models.

The third dimension - social practice is evident in practical policy implications, framed by the discourse. For example, what kind of information efforts does the text propose and what are the consequences of proposed preventive and treatment interventions? Finally, we shall link social practice to how alcohol policy interventions reconstruct power relations between men and women and thus the societal structures which both affect the discourse and are affected by it.

The texts analysed are: Alcohol Policy Inquiry Report (SOU 1974:90-93), Alcohol Policy Commission Report (SOU 1994:2429), and three government bills: National Action Plan to Prevent Alcohol Harm (prop. 2000/01:20), National Alcohol and Drug Action Plans (prop. 2005/06:30) and Renewed Public Health Policy (prop. 2007/08:110).

The first two reports represent the most comprehensive alcohol policy documents since the abolition of the ration book. No such ambitious reports have appeared since. For their part, the three government bills summarise the prevalent alcohol policy during the following years. These documents are different in their nature and size, exemplifying different stages of the parliamentary decisionmaking process. Yet they share something vital: they all constitute and embody the official alcohol policy discourse which influences the social practice on alcohol and alcohol-related problems.

Below we analyse each of the five papers under three headings: problems with women's and men's drinking; reasons for women's and men's drinking; and proposals for action.

\section{Alcohol Policy Inquiry Report}

The Alcohol Policy Inquiry (APU) was launched in 1965 by Social Democratic Minister of Finance Gunnar Sträng to examine the effects of abolishing the ration book. The committee was to scrutinise the correlation between alcohol prices and consumption and to map drinking habits among different social groups, particularly young people and women (SOU 1974:90, 3-13). In the committee's terms of reference it was also stated that a return to the previous restrictive system was out of the question. The committee's name reflects a new approach to alcohol problems, from temperance policy to alcohol policy (SOU 1974:90, 14). A distinction is made between alcohol policy and temperance policy. Temperence policy is seen to encompass a broader area of also dealing with treatment issues, which alcohol policy as interpreted by APU explicitly does not. The aim is no longer to achieve the highest possible number of abstainers in the population as the primary way of keeping down the number of addicts. The 1974 committee declares that it does not see the same clear link between the use and abuse of alcohol as the 1944 Temperance Committee did. The mere use of alcohol is not considered to cause any appreciable increase in the risk to abusing alcohol (SOU 1974:90, 95). Alcohol policy must therefore take into account that many people perceive 
alcohol as a positive element in their lives and the policy measures should accordingly have a positive thrust such as encouraging a shift to weaker alcoholic drinks, and education to teach people more responsible drinking habits and changed attitudes to alcohol (SOU 1974:90, 70; 1974:93, 12). APU's work comes in four parts of about 1,000 pages in total. The committee submitted its final report in 1974.

In line with the committee goals of defusing the role of alcohol by encouraging a move to weaker beverage options, medium-strength beer was sold in Swedish groceries from 1965 to 1977. A similar liberalisation took place in Finland, with devastating results also highlighted by contemporary Finnish alcohol researchers. The final APU report also discussed the concept of total consumption, but the authors decided not to let it affect the measures suggested, as it would have left a contradictory impression.

The Alcohol Policy Inquiry documents give plenty of examples of high interdiscursivity, pointing to a shift in the discursive order. Many of the comments on the proposal circulated for consideration were critical of the findings, recommending instead that a reduction of total alcohol consumption was a key task for alcohol policy (Johansson 2008). The Government Bill (prop. 1976/77: 108) which the committee work eventually led to, presented a change in policy in contrast to APU's liberalising guidelines, stating explicitly that the Swedish alcohol policy shall be guided by the principle of reducing total alcohol consumption. A more restrictive alcohol policy was thus in place from the mid-1970s to the mid-1980s: the sale of medium-strength beer was forbidden in groceries, alcohol advertising was banned, and the monopoly retail store was closed on Saturdays. These restrictive practices broke temporarily with the shift to a more alcohol-liberal policy, which had started with the abolition of the ration book in 1955 .

\section{Problems with women's and men's drinking}

The discourse in the Alcohol Policy Inquiry is essentially gender neutral. The report's three-dimensional perspective on alcohol - man, substance, and environment - is indirectly a description of men's drinking. Women are almost invisible. The report is based on the assumption that female and male patterns of drinking are the same, and while women's drinking is on a smaller scale and at a lower level, it is not of a different nature. Women's and men's alcohol use is thus only rarely separated. In some sentences women are mentioned specifically, in terms of being medically different, having diverse body types and different alcohol uptakes (SOU 1974:90, 25), or delirium and alcohol dependence occurring faster in women (SOU 1974:90,47; SOU 1974:93,10).

More often, the report points out that women's consumption had increased significantly after the abolition of the ration book (SOU 1974:90136, 237-251; SOU 1974:91, 94; SOU 1974:93, 25, 27, 44), though little attention is paid to gender differences in consumption habits. The increasing consumption among women is treated as serious, however, it is not discussed further. Rather, it is described as partly evil yet inevitable.

Therefore, it must be considered serious that the ongoing - in itself desir- 
able - trend towards equalisation between male and female tasks and behaviour, within the workplace and in other areas, apparently seems to lead to women's alcohol habits approaching men's. (SOU 1974:91, 94)

These formulations of the seriousness of women's changing habits and what these habits may lead to are somewhat cautious, expressed with a rather weak modality by the use of such words as "considered" and "apparently seems". No irrefutable fact is established. Female alcohol habits approaching those of the men are described as an inevitable part of a desirable development. The expression "in itself" weakens the obvious desirability of this development.

Alcohol consumers are at times referred to as males, as in the next example, which makes note of alcohol's positive impact on society in facilitating people-to-people contacts.

Alcohol may also help the individual to overcome inhibitions and tensions preventing him to make a satisfactory use of his personal opportunities. Other purposes' benefit to society may seem more questionable, such as attaining influence as an evidence of masculinity, to compensate for a lack of life satisfaction or as an escape from reality. (SOU 1974:93, 12)

The report's ambition to achieve more civilised relations to alcohol by playing it down and to adopt a non-moralising attitude can be seen in the discreet critique of male drinking habits: alcohol use may be a social lubricant, but other purposes of men's drinking "may seem more questionable".

Drinkers are also referred to as "he", when the risks of harms or adverse effects are discussed in relation to consumer behaviour. Also these formulations are chosen with great care to avoid moralising and offending self-regulating alcohol consumers.

The danger is determined by what the consumer does in relation to consumption. Consumption may be harmless if he goes to bed, however, if he decides to drive a car it should be considered risky. (SOU 1974:90, 19)

The man referred to above is an independent actor in control: "he" chooses whether to sleep or to drive. There is no strong condemnation in the form of generally accepted truths over the choice to drive under the influence of alcohol.

Pregnancy and alcohol is mentioned in a short section according to which there is not any firm evidence that a pregnant woman's alcoholism could result in malformations in the expected child. The report states, however, that some recent findings point in this direction. Whether low consumption levels could be a danger to the foetus is not discussed (SOU 1974:90, 39).

\section{Causes of women's and men's drinking} Societal structure is identified as a key explanation of alcohol misuse. Drawing attention to the drawbacks of modern development, the documents emphasise the increased demands, isolation and tempo, and urbanisation and problems of adaptation (SOU 1974:91, 83). While the report regards demands for greater productivity 
and efficiency as necessary to improving living conditions for the vast majority, it also considers these as contributing to exclusion from working life and community. Both these factors are seen as important for an understanding of the more widespread harms caused by alcohol (SOU 1974:91, 86).

The difference between the proportion of alcohol abusers among men and women is explained through gender roles, which condemn women's drinking (SOU 1974:93, 13; SOU 1974:91, 94; SOU 1974:90, 136).

In some cases, the importance of gender norms is clear. The proportion of female alcohol abusers are in all surveys considerably smaller than the proportion of male abusers. This is apparently to a large extent due to the norms governing the gender roles, which label high consumption and intoxication as non-female behaviours. (SOU 1974:93, p. 13)

Despite the repeated references to social structures, norms and gender roles, some uncertainty in these claims can be seen by the use of weakening modalities, such as "apparently" in the example above.

The report shows, however, no interdiscursivity in the form of alternative causal explanations. Social change and changing gender roles are the dominant explanations to women's changing drinking patterns. Men's drinking is explained by other causes, such as a search for masculinity and independence combined with social pressure to binge drink. Furthermore, it is noted that men have permissive attitudes to both the use and abuse of alcohol (SOU 1975: 91, 95).

\section{- Proposals for action}

APU's proposals for action reflect the desire to play down alcohol by changing attitudes rather than applying the newly acquired knowledge of the effects of total consumption. In discussing the role of information as a way of reaching alcohol policy objectives, the report hopes that traditionally feminine attitudes and values will be influencing men rather than vice versa.

Investigations during the 1970s show that the [gender] differences more and more are being erased. A goal for information can be to seek to influence this process. [... $)^{1}$ It is completely in line with the objectives APU sets for the alcohol policy to promote beliefs and values regarding alcohol associated with the role of women in society and let these dominate in such an equalising process, which concern both the age of the drinking debut as well as beverage choice, and the amount of consumption, and the attitudes towards intoxication. (SOU 1974:91, 178)

It is not clear if this information will be designed to portray women's alcohol habits as exemplary to men through information campaigns.

In conclusion, APU's gender-neutral descriptions construct a picture of alcohol consumers as self-regulating men. Women's alcohol consumption is seen only as a small-scale copy of men's consumption, not worthy of further scrutiny. Women's drinking remains essentially non-problematised and does not lead to any specific policy proposal other than indirectly the same as with men, which is moderation in drinking habits and transition to weaker 
beverages. Women drink less than men, because normative gender roles prevent them from drinking alcohol in the same way as men. Men, too, drink because of normative gender roles, but in their case the roles work in the opposite direction. Men have a social pressure to drink. When female alcohol consumption increases, it is seen as not entirely desirable, rather as consistent with emancipation.

\section{Alcohol Policy Commission Report}

In 1991, the Liberal Minister of Health and Social Affairs as well as Minister of Gender Equality Bengt Westerberg appointed the Alcohol Policy Commission, with representation of all the political parties in the Swedish Riksdag (Parliament). The Ministry of Health and Social Affairs has been responsible for alcohol issues in their entirety from the mid-1970s.

The commission submitted its final report in 1994. The task stated in the terms of reference was to evaluate the prevailing alcohol policy and submit a proposal for future guidelines in order to reduce total alcohol consumption, to limit alcoholrelated harms in the context of Sweden's future EU membership and to eliminate any unnecessary rules. So as not to risk undermining the public's confidence in the cornerstones of Swedish alcohol policy, alcohol restrictions should only apply where the public could perceive them as meaningful. The commission was also to pay attention to social consequences for families of alcohol abuse, and to revise treatment for alcohol abusers. Women's increasing abuse and pregnant women's alcohol habits were singled out as especially significant problems (SOU 1994:24,
241-248). Treatment issues were thus defined as part of alcohol policy, which was not the case in APU twenty years before.

The commission's reports consist of one main report and five partial reports totalling approximately 1,300 pages. The partial reports Women and Alcohol (SOU 1994:28) and Children, Parents, Alcohol (SOU 1994:29) are especially interesting for this paper, since this is where most of the gender comparisons are found.

\section{- Problems with women's}

\section{and men's drinking}

The commission states repeatedly that men's alcohol consumption is significantly higher than women's, that men consume about $70 \%$ of all alcohol and that a far greater proportion of men $-4-5$ times more men than women - have alcohol problems (see, for example, SOU 1994: 24, 193; SOU 1994: 25, 52; SOU 1994: 28, 27 ff; SOU 1994: 28, 67). It is also noted that the problems caused by men's abuse are far more costly to society than those resulting from women's abuse. This is because of the magnitude of men's drinking and their binge drinking behaviour (SOU 1994: 28, 17).

When women's drinking is described in more detail, however, both their use and abuse of alcohol are in several ways distinguished negatively from those of men. The commission may emphasise as one of its starting points that the causes and consequences of excessive alcohol consumption are essentially the same for women and men (SOU 1994: 28, 15), but the dominant image is that of women's drinking as different and more complex than men's. Male drinking is presented as more uncomplicated, mainly because it is established and traditional. 
Binge behaviour is more common among men and is easier accepted or tolerated for men as a result of this. Women are judged more severely, both by men and women, and they are more quickly defined as alcoholics if they show binge behaviour. (SOU 1994: 28, 26)

Women's more complex problems are attributed to the distancing and condemnation by those around them. This creates problems with shame and guilt, making women shy away and drink in solitude, which in turn generates additional problems.

There is a correlation between shame and guilt, hidden abuse and drinking alone. The reasons for women to often drink alone, and thus also hidden, may partly be sought in traditions and attitudes. Men are considered to have a more uncomplicated relation to alcohol. Roughly generalised, boys are introduced to alcohol by their peers and in company of their peers. For the adult man alcohol is often associated with being together with other men, such as at the pub. [...) An abusive husband and father are not blamed as strongly by those around them or by the authorities, as an abusive woman and mother. Own feelings of shame and control from others make the hidden abuse and sole drinking a necessity. Not being able to show or talk about the problem can increase the anxiety and feelings of debt. (SOU 1994:28, 38)

Here, women are described as victims of society's repressive norms, which leads to lone, shameful and guilt-stricken drinking, in turn creating a vicious circle of heightened problems. Drink in solitude appears as a necessity and is expressed with a strong modality. The same conditions do not apply to men. Boys'/men's drinking in company among friends stands out in positive contrast, although there is some hesitance in "is considered more uncomplicated" and "roughly generalised".

The commission also problematises girls' drinking on several occasions, making clear the links to sexuality (SOU 1994: $28,44,61)$. Both alcohol and sexuality are seen as girls' means to assert themselves.

Insecure and dependent girls seeking closeness and contact subordinate themselves to conditions set up by boys/men. The girl may get a certain status and a position in the group through the boy. To get contact, warmth and a relation she uses the means of alcohol in combination with sexual activity. (SOU 1994: 28, 44)

This is a picture of vulnerable and dependent girls. The report describes how their access to the outside world goes through boys. Sexuality is not assumed to play a positive role in itself; instead contact, warmth and relationship are superior and desired goals for these girls. This description of reality is expressed with a strong modality, further reinforced by the text's shift from describing a limited group of girls to the universal category of "the girl" and "she" (cf. Esseveld \& Elden 2002). Similar problems concerning boys' sexuality in relation to alcohol consumption are absent, which becomes even clearer in the discussion about sexual abuse. 
Alcohol, perhaps with intoxication, also means a greater risk for girls to be sexually exploited and subjected to abuse. (SOU 1994: 28, 44)

Although sexual abuse requires an offender, it is the alcohol-consuming, perhaps drunk, girl who is in focus. The perpetrator, boy or man - himself probably no stranger to alcohol and perhaps intoxicated - is invisible. The relationship between boys/men and alcohol and sexual abuse is obscured. The logic is that sexual abuse can be avoided if girls stay sober, while boys' and men's alcohol consumption remains invisible and unproblematised in this context.

The report mentions young men's drinking habits separately in discussing the importance of disseminating information to young men doing their compulsory military service.

Compulsory military service offers a unique opportunity to disseminate information about alcohol problems to a large group of young men. During this time there is a significant risk that alcohol habits learned during high school are intensified, and new more excessive alcoholic habits are learned. Therefore, there is every reason to try to counteract too high alcohol consumption during the compulsory military service. (SOU 1994: 24,147)

It is argued that compulsory military service is a unique opportunity to reach many young men in a situation where they run the risk of learning more excessive alcohol habits. It is a little surprising that it is not alcohol consumption that should be dis- couraged but excessive alcohol consumption. That the report has little faith in the possibilities of influencing male drinking culture through information activities, important as they are declared to be, becomes evident also in the feeble formulation of concrete proposals.

Security aspects also speak for recommendations that conscripts should [our italic) refrain from alcohol the evening before exercises with live ammunition or when other elements of risk are involved. (SOU 1994: 24,179)

\section{Causes of women's and men's drinking}

The difference between men's and women's drinking is described primarily in the female-specific causes of alcohol abuse. Unlike with men, women's alcohol abuse is seen as a consequence of complex underlying problems of individual and psychological nature (SOU 1994: 24, 194ff; SOU 1994: 28, 33, 35, 41). Below is an example:

Women's drinking is a symptom of psychological and psychiatric problems and difficulties, insecurity, low self-esteem, anxiety, agitation, palpitations, muscle tension, and depressive symptoms. Major depression often precedes abuse in women compared with men, in whom depression is more often a result of the abuse. Alcohol works as a form of self-medication. It reduces tensions, anxiety or depression. [...) Although many men have a similar problematic picture as women describe, men do not describe the reasons for using alcohol in the same way as women. Problems and prob- 
lem solving have been associated with women's alcohol use. It is also inevitable that many female alcohol abusers have underlying problems associated with sex, such as sexual abuse. (SOU 1994: 28, 41)

The consistently strong modality in reporting the complex underlying reasons for female drinking renders them the quality of established facts. Here, too, men are presented in positive contrast to women. The women's situation is repeatedly characterised by vulnerability and dependency, with resultant high alcohol consumption. "Complex" is a recurrent word to depicting this intricate underlying image of many causes (SOU 1994: 24, $194 \mathrm{ff}$; SOU 1994: 28, 33, 35, 41, 69).

We can also trace a certain degree of interdiscursivity in the commission's report. The document discusses explanations given in APU, which emphasised women's changing social position and the increasing similarities with men's living conditions, but does not find them very plausible as reasons to women's drinking (SOU 1994: 24, 194ff; SOU1994: 28, 35, $36,41,44)$. The report does not unequivocally support the view of a correlation between working conditions and high alcohol consumption, either for men or for women. For career women, however, male colleagues are seen as a contributing risk factor for high alcohol consumption. Elsewhere, too, in the report, men are assigned a significant role to why women start drinking heavily. For example, older boys are depicted as making girls start to drink (SOU 1994: 28, 33). Furthermore, whether heavy drinkers or not, men are described as barriers to women who want to come to grips with their alcohol problems.

One obstacle to the woman to seek and receive help is that the spouse/partner, who often himself is an alcohol abuser, is opposed to treatment as his wife/partner then may get a different attitude to alcohol and thus also to his abuse. (SOU 1994: 28, 66)

Men are also portrayed as less loyal to their abusive wives than are women to their abusive husbands.

The man, who is not an abuser, does not generally or does not want to see the wife's abuse. He turns a blind eye to the problems as long as he can. When the abuse is no longer possible to keep within the family, divorce is the solution for the man. (SOU 1994: $28,50)$

The consequences could be disastrous for the already vulnerable and exposed women.

The woman is also physically abandoned and the problematic situation does not infrequently lead to dramatic events such as substantially increased abuse, intoxication, suicide or suicide attempts, etc. (SOU 1994: 28, 50)

The assertions in the three quotes above are expressed with a strong modality. The statements have the character of universal truths, valid for all women with alcohol problems and also for all men who have wives with alcohol problems, reinforced by "the man" and "the woman" in definite singular form. The women's ability to act independently is presented as heavily lim- 
ited, and their situation seems largely dependent on conditions set by male actors. A small reservation appears in "not infrequently" and "in general”, which weakens the general assertion.

The report also discusses and compares causes of girls' and boys' alcohol consumption. As with women, girls' alcohol use is seen as a way of escaping negative emotions and mental stress.

Girls who start high consumption of alcohol are using alcohol as a means to escape from problems in the family with ignoring, rejecting or controlling parents. Alcohol reduces tensions and compensates for low self-esteem and feelings of being marginalised. Boys' consumption is governed more by peer influence, peer interaction and their own desire to act "masculine". (SOU 1994: 28, 43)

Here, the report defines who girls and boys are in general, and what they do. This excerpt, too, is characterised by a strong modality. No room is given to alternative explanations. Crucial for high alcohol consumption among girls is their lack of positive family relationships and low self-esteem. Girls drink to escape personal problems and family dependence. In contrast, boys' alcohol consumption is "just" consumption - not high consumption - and their drinking is seen as an active behaviour in order to reach a desired goal and adulthood in the company of peers. For girls, alcohol is thus described as a means to escape from negative elements in life, whereas for boys it is an opportunity to achieve something positive and desirable.

\section{Proposals for action}

The report states that women's increasing consumption calls for increased attention and preparedness to prevent an unfavourable outcome (SOU 1994: 28, 77). In drawing attention to the differences between men's and women's drinking, it is essential to meet women's special needs in seeking help and support, and in treatment situations (SOU 1994: 28, 18; SOU 1994: 24, 115). Alcohol-abusive women are judged to need a different type of treatment than men in the same situation (SOU 1994: 27, 158-159; SOU 1994: 28, 68ff).

Women generally need longer time in treatment than men. One explanation given is that men can be treated for their alcohol abuse and can be recovered when sobriety has come about. Women usually have an underlying problem, often psychological, which means that they need a different treatment than solely help to become sober. (SOU 1994:28, 68)

In the section on pregnancy and alcohol it is clear that research is partly contradictory, especially on the risk of birth defects at lower levels of consumption. It is clear, however, what pregnant women should be told:

The aim should be that all pregnant women shall have such knowledge of the risks associated with alcohol use during pregnancy that they voluntarily choose to refrain from all use and that they regard pregnancy as a period in life when no alcohol is consumed. (SOU 1994: 24, 140) 
It may appear contradictory that all pregnant women should have knowledge of something the authors of the report do not have themselves. A plausible interpretation is that the knowledge which is to be mediated to women will be selected in such a way that the natural choice is to abstain from all alcohol use throughout pregnancy. However, the wording of the report does not leave room for ambiguity. Alcohol use among pregnant women shall be discouraged in a "powerful" way (SOU 1994: 24, 13). Furthermore, it is noted that some women may need "further work" in order to be induced to refrain from alcohol, and it is important to discern these women by discovering “who's who” (ibid. 140).

In conclusion, the commission pays attention to and problematises women's drinking much more and in a completely different way compared to the preceding Alcohol Policy Inquiry. Explanations of women's increased drinking on the basis of their changing participation in the labour market are discussed but rejected in favour of reasoning from an individual psychological perspective. Girls' increased alcohol consumption is repeatedly addressed and problematised in relation to sexuality. Alcohol and pregnancy features prominently in spite of the partly contradictory research findings. The report also discusses women's specific needs in terms of prevention, care and treatment. Throughout, both women and girls are presented as dependent, powerless and emotionally vulnerable to men around them. Men's drinking comes out as a positive contrast in comparison to women's drinking, although the commission also shows that men account for the vast majority of alcohol consumption and related problems. Men's problems are described as less complex and less difficult to treat because their drinking is better tolerated by society and men are not blamed the same way as women are for drinking.

The language of the report is almost entirely gender-neutral, when not discussing women's or girls' use and abuse of alcohol. The paradoxical effect is that of tolerance and the toning down of problems associated with male drinking behaviour, demonstrated in the section on young men's alcohol habits during military service.

\section{National Action Plan to Prevent Alcohol Harm}

The Government Bill National Action Plan to Prevent Alcohol Harm (prop. 2000/01: 20) was presented to the Swedish Riksdag by Social Democratic Prime Minister Göran Persson and Social Democratic Minister of Health and Social Affairs Lars Engqvist against the backdrop of EU regulations on the private import of alcohol taking full effect as of 2004. The bill's main thrust is to propose a variety of measures at the local municipal level to counteract the effects expected when Swedes have access to considerably cheaper alcohol from abroad. The introduction of the bill maintains that the national alcohol policy still seeks to reduce total consumption as a way to limit medical and social harms caused by alcohol. The bill contains nearly 100 pages of text.

\section{Problems with women's} and men's drinking

The bill notes, without further comment, that women's drinking increased after the ration-book period, that the difference in consumption between sexes remained 
relatively constant during the 1980s and 1990s, that men drink 2-2.5 times more than women, and that men in the $1960 \mathrm{~s}$ drank 4 times more than women (ibid. 10).

A section dealing with alcohol and pregnancy is based largely upon the previous Alcohol Commission's report. While acknowledging that there are no studies of how many children are harmed as a result of women drinking alcohol during pregnancy, the bill expresses a fear that the number of children born with birth defects will increase.

Some researchers estimate that at least two to three percent of all women in Sweden have alcohol problems, and just over one percent of pregnant women. Overall, this may signify a risk that the proportion of children born with FAS [fetal alcohol syndrome] or FAE [fetal alcohol effects] may increase. (Government Bill 2000/01: 20, 74)

The choice of words conveys a relatively weak modality. The truth claim is toned down by the words "some researchers" and "may signify a risk". Together with the absence of references this gives a far from clear-cut impression.

\section{- Proposals for action}

Although there is still uncertainty about how many women drink during pregnancy and at what level alcohol is dangerous to the foetus, alcohol-free pregnancies are identified as a priority of alcohol policy (Government Bill 2000/01: 20, 38). Child care centres should also provide information on the effect of alcohol during lactation (ibid. 75). What information is to be given or how alcohol affects breast-feeding is, however, not mentioned.

In summary, the only gender-specific alcohol problem in the bill is women's drinking during pregnancy.

\section{National Alcohol and Drug Action Plans}

The Government Bill National Alcohol and Drug Action Plans (prop. 2005/06: 30) was presented to the Swedish Riksdag by Social Democratic Prime Minister Göran Persson and Social Democratic Minister och Health and Social Affaires Morgan Johansson. The action plan to prevent alcohol-related harms takes up about 80 pages of the bill. At the outset, the action plan determines the aim of alcohol policy as promoting public health by reducing medical and social harms caused by alcohol. Cut down total alcohol consumption and harmful drinking behaviour through efforts which are sensitive to girls', women's, boys' and men's differences in living conditions, the bill says, and apply an explicit gender perspective at all levels of alcohol policy (ibid.1).

\section{Problems with women's and men's drinking}

The action plan notes that men drink more than twice as much alcohol as women, but women's consumption has increased significantly in the longer term (ibid 8). Although men drink more and face more alcohol-related problems, it is the change in women's drinking that causes concern. In constructing the problem of women and alcohol, the action plan is in many ways similar to the 1994 Alcohol Policy Commission Report. New elements, however, have entered in the text. The most obvious change 
is shifting attention primarily toward girls and their mental health. Adult women are not addressed to the same extent.

\section{- Causes of women's and men's drinking}

Again, women's drinking is understood on the basis of complex underlying factors. In a short section, the Action Plan discusses specific female causes of alcohol abuse.

Among the key factors behind alcohol abuse among women are precarious family relationships in childhood and the experiences of early sexual abuse. (Government Bill 2005/06: 30, 35)

The significance of these explanations is stated with a strong modality. It is not clear if they are significant because they are commonplace, or because they show an unusually strong correlation with later alcohol abuse, or simply because of their serious nature. A number of new factors are considered to interact with later alcohol abuse in women, which are similarly expressed with a strong modality.

There are several correlations between early problem behaviours, restlessness, and early sexual debut with increased risk for alcohol abuse later in life. These correlations need to be further clarified. (Government Bill 2005/06: 30, 35)

What these correlations look like is not described and neither are "early problem behaviour" or "restlessness" defined. Notable is also the return of the same problematising link between girls, alcohol and sexuality as in the 1994 Alcohol Policy Commission's Report and the absence of a similar link on boys, alcohol and early sexual debut.

That girls feel bad is taken as a given. The Action Plan finds that there is evidence of girls "generally" feeling worse. The girls" "situation" is marked by suicide attempts, self-destructive behaviour, eating disorders and depression (Government Bill 2005/06: 30, 45). This image is then vaguely linked to increased drinking among girls, and is thereby constructed as one of many expressions of girls' mental problems.

There are several indications that the same girls who exhibit these risk behaviours also have high alcohol consumption, however, there is a lack of knowledge of the possible correlations between girls' situation and the increase in alcohol consumption among girls. (Government Bill 2005/06: 30, 45)

The modality of the text is fairly weak, with reservations such as "several indications", "lack of knowledge" and "possible correlations". The text nevertheless associates girls' alcohol consumption to a wide range of destructive behaviours without proof of any such correlation. What is communicated is an image of girls who drink because they feel bad. That they feel bad is the problem. Gender-specific problems concerning alcohol and boys are not conveyed. Boys and young men come implicitly in the gender-neutral categories of young people, teenagers and young adults.

\section{- Proposals for action}

The Action Plan stresses the need for indepth knowledge about differences in men's and women's alcohol consumption 
and alcohol-related problems, and the need for developing interventions with an explicit gender perspective within prevention, care and treatment. In addition, the plan points at the importance of further clarifying the relationship between new factors (problem behaviour, restlessness, early sexual debut) which are expected to correlate with alcohol abuse (Government Bill 2005/06: 30, 34-35).

To summarise, the 2005 Action Plan presents a picture rather similar to that of the 1994 Alcohol Policy Commission. One change is the shift in focus from adult women to girls. Girls' drinking is seen as a problem at the individual level and a manifestation of mental illness with references to "problem behaviours", "restlessness" and "early sexual debut".

\section{Renewed Public Health Policy}

The Government Bill Renewed Public Health Policy (prop. 2007/08: 110) was presented to the Swedish Riksdag by Moderate $^{2}$ Prime Minister Fredrik Reinfeldt and Christian Democratic Minister of Health and Social Affairs Maria Larsson. A previous Government Bill, Goals for Public Health (prop. 2002/03: 35), had identified eleven different target areas for public health policy, discussing alcohol on one page towards the end along with tobacco, drugs, doping and gambling. It is as though alcohol policy has been dissolved and absorbed by other public health policy issues (Tigerstedt 1999). At times, however, alcohol continues to worry depending on who drinks it. Some women keep giving cause for concern, as is seen in the Renewed Public Health Policy; four pages out of 122 are devoted to alcohol.

\section{Problems with women's and men's drinking}

The Renewed Public Health Policy confirms a mainly positive course of health in Sweden. This applies to a whole range of public health problems, including those caused by alcohol. Drug use surveys of young people show a downward trend. Alcohol-related mortality has declined since the 1980s, and alcohol-related harms have not increased as expected. The Government Bill notes that the estimated proportion of risk consumers among 18-24-year-old men amounted to 17 percent in $2004-9$ percent for young women - and that most risk consumers were in the age group of 18-29 years (ibid. 101). The health care system is expected to pay attention to risk consumers and support them in changing their habits.

There are, however, some areas of worry in the generally positive health situation. Young women and alcohol emerges as a separate problem linked to their mental health status while nowhere in the document is there a distinct discussion of any problems regarding men/boys and alcohol.

There are also negative signs. Evidence suggests that particularly young women have a precarious health situation. In interviews, the proportion of women, aged 16-24 years, who report both easy and difficult problems with anxiety, nervousness or apprehension, has increased since the mid-1990s. Young women have during the same period increased their alcohol consumption (with the exception of the last two years), and are increasingly treated for alcohol poisoning and have to an increasing extent made suicide attempts. (Government Bill 2007/08: 110, 27) 
By first declaring increases in young women's mental health problems, unsupported by facts, and then in general terms describing increased alcohol consumption, alcohol poisoning and suicide attempts, the text suggests an indication of causality. The Government Bill does not, however, say anything about how prevalent these problems are or how they might correlate with one another. The formulations are remarkably similar to those of the National Alcohol and Drug Action Plans (prop. 2005/06: 30), while the modality is even stronger. Some room is left for doubt in the wording "evidence suggests", but no need for additional knowledge is proposed.

The subject of women, alcohol and pregnancy is given more than one page in total. The length of the segment is justified by a possible change in the law. To protect the foetus, the government introduces the possibility of compulsory treatment of mothers.

The National Board of Health and Welfare notes in the report Pregnant Women with Substance Abuse and Children Living in Families with Abuse that there is a need to strengthen the treatment offered to pregnant women with abuse problems. [...) Based on the report from the National Board of Health and Welfare, the Government intends to come back with proposals on how support to pregnant women with abuse problems can be developed. As a complement to medical treatment in voluntary forms, and as a protection for the unborn child it should be possible to apply for compulsory treatment of those women who are unable to cease abusing according to the law
(1988:879) On Treatment of Drug Users in Some Cases (LVM). The aim is that children shall not be born with defects caused by maternal consumption of alcohol or drugs. Such an extension of LVM means that women who today do not receive voluntary treatment will be receiving treatment at an earlier stage of their pregnancy than what is happening today. The earlier in pregnancy a woman receives treatment, the better the start in life will be for child. The National Board of Health and Welfare writes in its report that a majority of staff who come into contact with these women think that LVM should be changed in order to provide expanded opportunities for compulsory treatment of pregnant women with abuse problems. (Government Bill 2007/08: 110, 102-103)

The strong modality of the formulation demonstrates certainty. The text does not hesitate: children shall not be born with harm caused by the mother's use of alcohol or drugs. And yet, the text fails to clarify who these pregnant women are not reached already - to be reached by changed legislation. The interdiscursivity of the bill through a number of references to a National Board of Health and Welfare report clearly serves to strengthen the argument. At the same time, the bill omits mentioning the doubts this report voices against extended possibilities of compulsory treatment. Also, it is dubious to claim that most of the staff who come into contact with women with substance abuse advocate a change in the law. While 23 of the 36 treatment units in charge of treatment for pregnant women with abuse problems 
are positive to a change, it is entirely different to say that this applies to a majority of the staff in contact with women at risk of harming their foetuses by using alcohol or drugs during pregnancy.

\section{Causes of women's and men's drinking and proposals for action}

Apart from young women's mental illness, which is linked to their drinking in an unclear way, the Government Bill does not cite any other reasons for drinking than the availability of alcohol. This emerges as a cause for the whole population. The measures suggested are health care interventions for problem groups, but no separate measures are given for men and women, except that maternal health care should be improved to protect the foetus by the announced change in the law regulating compulsory treatment. Men are invisible, whereas women are made visible as containers of the expected child and in relation to mental illness.

\section{Conclusions}

The 1974 Alcohol Policy Inquiry report (SOU 1974: 90-93) refers to women as a reflection of men, only reduced in scale. Citing traditional gender roles, which condemn women's drinking, the report explains why female alcohol consumption has traditionally been so much lower than that of males. Women's increased drinking is understood on the basis of changing gender roles and through their entry in the labour market. Men drink also because traditional gender roles put pressure on them to drink and act masculine. The more cautious female drinking is singled out as exemplary.

Moving on twenty years, the 1994 report of the Alcohol Policy Commission (SOU 1994: 24-29) gives a prominent place to women and their use and abuse of alcohol. In this report, causal explanations for women's drinking habits have shifted from social changes to the level of the individual. High alcohol consumption by women is seen mainly as a consequence of mental problems such as anxiety, depression and low self-esteem. Compared to men, the visibility of women leads to the construction of entirely different, partly pathological reasons to drink and abuse. When men are particularly highlighted, it is as a positive contrast to women.

None of the two above explanations is to be found in the National Action Plan to Prevent Alcohol Harm (prop. 2000/01: 20). Apart from a section on pregnancy and alcohol, women's and men's uses or abuses of alcohol are not separated and no gender-specific causes of female or male alcohol abuse are discussed. For its part, the National Alcohol and Drug Action Plans (prop. 2005/06: 30) returns to personal problems and early victimisation as causes of women's high consumption of alcohol. The problem descriptions of women's mental health, their sexuality and reproductive role are largely the same in 1994 as in 2005, with the difference that the latter is more concerned with girls and their mental illness, said to be on the increase. What is prominent in both documents is girls' sexuality, negatively charged regardless of whether it is associated with alcohol or not. Both sexuality and alcohol are cited as destructive means of expression for vulnerable girls. In the Renewed Public Health Policy (prop. 2007/08: 110), the focus is almost exclusively on women's reproductive role. 
Problematising related to women's alcohol consumption during pregnancy is found in varying forms in all the studied documents. The reasoning of the 1994 report and the two national action plans from 2000 and 2005 is similar in that there is a certain gap between the actual knowledge reported on the issue and the recommended guidelines. Even though the references to research on alcohol and birth defects are partially incomplete, and sometimes even contradictory, the documents are much more decisive about what information is to be given to pregnant women. In addition, the 2007 Government Bill has disregarded the doubts presented in the document on which this bill is based.

The discourses identified above confirm the basic logics of the gender system (Hirdman 2001). The first discourse reproduces a hierarchical logic in the sense of man as the norm. At times, when the 1974 report of the Alcohol Policy Inquriy mentions the drinker's gender, it is a "he", and this "he" is reproduced as a self-governing consumer. Women's alcohol consumption is mentioned as essentially similar to that of men.

The discourse implicit in the following alcohol action plans represents a separating logic, which according to Hirdman generates a logic of hierarchy. Over time, when they have entered previous male domains, an "extra room" has been created for women (Hirdman 2001, 114ff). When women's alcohol habits are foregrounded as apart from men's, women end up being defined as more problematic than men. The separation of women is motivated by the need to address their special problems in order to better meet their requirements for support, treatment and prevention.
The result, however, is a representation of women as dependent, powerless and victims of men.

This involves a remarkable interplay with, and effect on, the social practice. It can be seen, for example, in treatment research which has in recent years raised considerable criticism of the consequences of treatment of women. The treatment has drawn on the idea that women are particularly difficult to treat because of psychological problems and issues with female identity (see e.g. Laanemets \& Kristiansen 2008; Mattsson 2005). The criticism pertains, for example, to a conveying of stigmatising values, which in reality affect not only women who abuse. Such values contribute to constructing an image of women with addiction problems as strange and different, living under completely different conditions compared to other women. In addition, the emphasis on the differences between men and women in treatment risks making the similarities between men and women invisible. They also mask differences within the same sex, based on identity belongings other than gender, such as class, sexuality or ethnicity.

In the same way - when the 1994 and 2005 documents make women visible by depicting them gender-stereotypically as dependent and limited by men and indirectly responsible for men's sexual acts, or by defining women's reasons to drink in terms of individual psychological disorders - these documents help to construct a normative vision of how women should be and behave. This has a disciplining effect on all women. At the same time, men's actions are normalised and constructed as free from responsibility. The normative picture the documents construct is that of 
men in control of their bodies and free to act. Women emerge as restrained by their bodies, clearly unfree. The female body is trapped by a biological reasoning about sexuality and reproduction (Eduards 2007), while men are left alone. The documents contribute to reconstructing separate expectations and claims on women's and men's self-regulation of alcohol, thus to reconstruct power relations between men and women.

However, it is not only women who are subjected to the gender order which creates one gender as superior to another. Men, too, are being pressed into genderstereotypic behaviours. Men's drinking is an important resource of expressing a masculine identity (De Vissner \& Smith 2007). It is a masculine ideal to tolerate copious amounts of alcohol and consistently to ignore or diminish the consequences of high alcohol consumption both for yourself and for other men. To be a man equals not admitting needing help with personal problems (Courtenay 2000). Women may present themselves as weak and needy and still be feminine, whereas dependent and help-seeking men are more easily judged from a gender-stereotypical viewpoint, seen as non-men and as subordinated masculinities (Connell 2008). Men who at one time or another find themselves in a dependent position are therefore viewed as losers - at least for a while - in the order of power that creates some patterns of masculinity subordinated to others. Therefore, when the documents construct men in a positive light compared to women, men's problems with alcohol are overlooked, and their need for qualified support to quit drinking diminished.

We suggested at the beginning of the article a political challenge. Prevention measures and help with alcohol problems need to be perceived as adequate by men, particularly young men and high-income earners. Our examination shows that the national alcohol policy action plans instead have chosen the easy path of problematising women's alcohol consumption with reference to their sexuality and mental illness and female bodies as containers of foetuses. The challenge is therefore to articulate an alcohol policy that opens its eyes to men's predicament and to organise help for alcohol problems in such a way as is attractive and non-stigmatising for both men and women.

Maria Abrahamson, Researcher Center for Social Research on Alcohol and Drugs (SoRAD)

Stockholm University

SE-10691 Stockholm, Sweden

E-mail: maria.abrahamson@sorad.su.se

Karin Heimdahl, Research assistant

Center for Social Research on Alcohol and

Drugs (SoRAD)

Stockholm University

SE- 10691 Stockholm, Sweden

E-mail: karin.heimdahl@sorad.su.se

\section{NOTES}

1) $[\ldots]$ means that text has been left out to save space without changing the meaning of the quotation.
2) "Moderate" can be translated as Liberal/ Conservative. 


\section{REFERENSER}

Abrahamson, M. (2003): Alcohol in courtship contexts: focus group interviews with young Swedish women and men. Contemporary Drug Problems 31: 3-29

Boman, U. \& Engdahl, B. \& Gustafsson, N.-K. \& Hradilova Selin, K. \& Ramstedt, M. (2006): Alkoholkonsumtionen i Sverige fram till år 2005. (Alcohol Consumption in Sweden up to 2005) Forskningsrapport 39, Centrum för socialvetenskaplig alkoholoch drogforskning (SoRAD), Stockholms universitet. www.sorad.su.se.

Bruun, K. (1985): Kön och klass. In: Bruun, K. \& Frånberg, P. (red.): Den svenska supen. En historia om brännvin, Bratt och byråkrati. (Swedish Booze. A History of Booze, Bratt and Bureaucracy) Stockholm: Prisma

Connell, R.W. (2008): Maskuliniteter. (Masculinities) Göteborg: Daidalos

Courtenay, W.H. (2000): Constructions of masculinity and their influence on men's well-being: a theory of gender and health. Social Science \& Medicine 50: 1385-1401

De Vissner, R. \& Smith, J. (2007): Alcohol consumption and masculine identity among young men. Psychology and Health 22(5): 595-614

Eduards, M. (2007): Kroppspolitik. Om Moder Svea och andra kvinnor. (Body Politics. On Mother Svea and Other Women). Stockholm: Atlas akademi

Eriksen, S. (1999): Alcohol as a gender symbol. Scandinavian Journal of History 24(1): $45-73$

Esseveld, J. \& Eldén, S. (2002): Frånvarande kvinnliga subjekt - en analys av medicinska texter om klimakteriet. (Missing Female Subjects - an Analysis of Medical Texts on Menopause). Kvinnovetenskaplig tidskrift nr 2-3: 45-59

Fairclough, N. (1992): Discourse and social change. Cambridge: Polity Press.

Fillmore, K. M. (1984): "When angels fall”: Women's drinking as cultural preoccupation and as reality. In: Wilsnack, S. \& Beckman, L. (eds.): Alcohol Problems in Women. Antecedents, Consequences and Intervention. New York, London: The Guilford Press
Hirdman, Y. (2001): Genus - om det stabilas föränderliga former. (Gender - on the Stability of Changing Forms). Malmö: Liber AB Hradilova Selin, K. (2004a): Dryckesvanor i den svenska befolkningen. (Drinking habits in the Swedish population) In: Hradilova Selin, K. (red.): Svenska dryckesvanor och deras konsekvenser i början av det nya millenniet. (Swedish Drinking Habits and their Consequences at the Beginning of the New Millennium) Forskningsrapport 20, Centrum för socialvetenskaplig alkoholoch drogforskning (SoRAD), Stockholms universitet

Hradilova Selin, K. (2004b): Alkoholrelaterade problem i olika befolkningsgrupper. (Alcohol- related propblems in different population groups). In: Hradilova Selin, K.(red) Svenska dryckesvanor och deras konsekvenser i början av det nya millenniet. (Swedish Drinking Habits and their Consequences at the Beginning of the New Millennium) Forskningsrapport 20, Centrum för socialvetenskaplig alkoholoch drogforskning (SoRAD), Stockholms universitet

Johansson, L. (2008): Staten, supen och systemet. Svensk alkoholpolitik och alkoholkultur 1855-2005. (State, Booze and Retail Monopoly. Swedish Alcohol Policy and Alcohol Culture 1855-2005). Stockholm/ Stehag: Brutus Östlings bokförlag Symposion

Knobblock, I. (1995): Systemets långa arm - en studie av kvinnor, alkohol och kontroll i Sverige 1919-1955. (The Long Arm of the Retail Monopoly - a Study of Women, Alcohol and Control). Stockholm: Carlssons

Laanemets, L. \& Kristiansen, A. (2008): Kön och behandling inom tvångsvård. En studie av hur vården organiseras med avseende på genus. (Gender and Treatment within Compulsory Treatment. A Study of How Treatment is Organized Considering Gender). Stockholm: Statens institutionsstyrelse (SiS). Forskningsrapport nr 12008

Leifman, H. (2003): Vilka dricker mer alkohol i Sverige? En studie av konsumtionstrender bland män och kvinnor i olika åldersgrupper under perioden 1990 till 2002. (Who 
drinks more Alcohol in Sweden. A Study of Consumption Trends among Different Age Groups of Men and Women During the Period 1990-2002.) Nordisk alkohol- \& narkotikatidskrift 20 (2-3): 159-180

Mattsson, T. (2005): I viljan att göra det normala. En kritisk studie av genusperspektivet i missbrukarvården. (In the Will to Do the Normal. A Critical Study of the Gender Perspective in Addiction Treatment.) Malmö: Egalité

Mäkelä, K. \& Room, R. \& Single, E. \& Walsh, B. (1981): Alcohol Society and the State 1. A Comparative Study of Alcohol Control. A Report of the International Study of Alcohol Control Experiences, in Collaboration with the WHO Regional Office for Europe. Toronto: Addiction Research Foundation

Measham, F. (2002): "Doing drugs": conceptualizing the gendering of drugs cultures. - "Doing gender" Contemporary Drug Problems 29 (2): 335-373

Ramstedt, M. (2004): Alkoholkonsumtion och risken för alkoholrelaterade problem bland svenska kvinnor och män - en riskkurvsanalys. (Alcohol consumption and the risk of alcohol-related problems among Swedish women and men). In: Hradilova Selin, K. (red.): Svenska dryckesvanor och deras konsekvenser i början av det nya millenniet. (Swedish Drinking Habits and their Consequences at the Beginning of the New Millennium) Forskningsrapport 20, Centrum för socialvetenskaplig alkoholoch drogforskning (SoRAD), Stockholms universitet

Prop. 1976/77:108. Regeringens proposition (Government Bill) 1976/77:108 om alkoholpolitiken. Socialdepartementet. (On Alcohol Policy. Ministry of Health and Social Affairs)

Prop. 2000/01:20 Nationell handlingsplan för att förebygga alkoholskador. (National Action Plan to Prevent Alcohol Harm.) Stockholm: Socialdepartementet. (Ministry of Health and Social Affairs)

Prop. 2002/03:35 (Government Bill) Mål för folkhälsan. (Goals for Public Health). Stockholm: Socialdepartementet. (Ministry of Health and Social Affairs)

Prop. 2005/06:30 (Government Bill) Nationella alkohol- och narkotikahandlingsplaner. (National Alcohol and Drugs Action Plans). Stockholm: Socialdepartementet. (Ministry of Social Affairs)

Prop. 2007/08:110 (Government Bill). En förnyad folkhälsopolitik. (Renewed Public Health Policy). Stockholm: Socialdepartementet. (Ministry of Health Social Affairs)

SoRAD (2008): Den totala alkoholkonsumtionen i Sverige under första kvartalet 2008. (Total Alcohol Consumption in Sweden during the first quarter of 2008). Centrum för socialvetenskaplig alkohol- och drogforskning (SoRAD), Stockholms universitet www.sorad.su.se.

SOU 1974: 90 Alkoholpolitik. Bakgrund. Betänkande D1. Alkoholpolitiska utredningen. Finansdepartementet. (Alcohol Policy. Background. Report D1. Alcohol Policy Inquiry). Ministry of Finance). Stockholm: Liber förlag/Allmänna förlaget

SOU 1974: 91 Alkoholpolitik. Åtgärder. Betänkande D2. Alkoholpolitiska utredningen. Finansdepartementet. (Alcohol Policy. Measures. Report D2. Alcohol Policy Inquiry. Ministry of Finance). Stockholm: Liber förlag/Allmänna förlaget

SOU 1974: 92 Alkoholpolitik. Bilagor. Betänkande D3. Alkoholpolitiska utredningen. Finansdepartementet. (Alcohol Policy. Supplements. Report D3. Alcohol Policy Inquriy. Ministry of Finance). Stockholm: Liber förlag/ Allmänna förlaget

SOU 1974: 93 Alkoholpolitik. Sammanfattning. Betänkande D4. Alkoholpolitiska utredningen. Finansdepartementet. (Alcohol Policy. Summary. Report D4. Alcohol Policy Inquriy. Ministry of Finance). Stockholm: Liber förlag/ Allmänna förlaget

SOU 1994:24 Svensk alkoholpolitik - en strategi för framtiden. Huvudbetänkande. Alkoholpolitiska kommissionen. Socialdepartementet. (Swedish Alcohol Policy - A Strategy for the Future. Main Report. Alcohol Policy Commission. Ministry of Health and Social Affairs.) Stockholm: Fritzes

SOU 1994: 25 Svensk alkoholpolitik bakgrund och nuläge. Delbetänkande. Alkoholpolitiska kommissionen. Socialdepartementet. (Swedish Alcohol Policy - Background and Present State of Affaires. 
Partial Report. Alcohol Policy Commission. Ministry of Health and Social Affairs). Stockholm: Fritzes

SOU 1994:26 Att förebygga alkoholproblem. Delbetänkande. Alkoholpolitiska kommissionen. Socialdepartementet. (Preventing Alcohol Problems. Partial Report. Alcohol Policy Commission. Ministry of Health and Social Affairs). Stockholm: Fritzes

SOU 1994:27 Vård av alkoholmissbrukare. Delbetänkande. Alkoholpolitiska kommissionen. Socialdepartementet. (Treatment of Alcohol Abusers. Partial Report. Alcohol Policy Commission. Ministry of Health and Social Affairs). Stockholm: Fritzes

SOU 1994:28 Kvinnor och alkohol. Delbetänkande. Alkoholpolitiska kommissionen. Socialdepartementet. (Women and Alcohol.
Partial Report. Alcohol Policy Commission. Ministry of Health and Social Affairs). Stockholm: Fritzes

SOU 1994: 29 Barn föräldrar alkohol. Delbetänkande. Alkoholpolitiska kommissionen. Socialdepartementet. (Children Parents Alcohol. Partial Report. Alcohol Policy Commission. Ministry of Health and Social Affairs). Stockholm: Fritzes

Tigerstedt, C. (1999): Det finns inte längre någon alkoholpolitik.(There is no alcohol policy any longer) Nordisk alkohol- \& narkotikatidskrift 16(2): 79-90

Wilsnack, R-W. \& Wilsnack, S-C. (1997): Introduction. In: Wilsnack, R-W. \& Wilsnack S-C. (red.): Gender and alcohol - individual and social perspectives (pp. 1-18). New Jersey: New Brunswick. 
